\title{
Isotopic Abundance Ratio Analysis of Biofield Energy Treated Indole Using Gas Chromatography-Mass Spectrometry
}

\author{
Mahendra Kumar Trivedi ${ }^{1}$, Alice Branton ${ }^{1}$, Dahryn Trivedi ${ }^{1}$, Gopal Nayak ${ }^{1}$, Kalyan Kumar Sethi ${ }^{2}$, \\ Snehasis Jana ${ }^{2, *}$ \\ ${ }^{1}$ Trivedi Global Inc., Henderson, USA \\ ${ }^{2}$ Trivedi Science Research Laboratory Pvt. Ltd., Bhopal, Madhya Pradesh, India
}

Email address:

publication@trivedisrl.com (S. Jana)

*Corresponding author

\section{To cite this article:}

Mahendra Kumar Trivedi, Alice Branton, Dahryn Trivedi, Gopal Nayak, Kalyan Kumar Sethi, Snehasis Jana. Isotopic Abundance Ratio Analysis of Biofield Energy Treated Indole Using Gas Chromatography-Mass Spectrometry. Science Journal of Chemistry.

Vol. 4, No. 4, 2016, pp. 41-48. doi: 10.11648/j.sjc.20160404.11

Received: May 10, 2016; Accepted: August 2, 2016; Published: August 21, 2016

\begin{abstract}
The objective of the current experiment was to evaluate the effect of biofield energy treatment on the isotopic abundance ratio of $\mathrm{P}_{\mathrm{M}+1} / \mathrm{P}_{\mathrm{M}}\left({ }^{2} \mathrm{H} /{ }^{1} \mathrm{H}\right.$ or ${ }^{13} \mathrm{C} /{ }^{12} \mathrm{C}$ or $\left.{ }^{15} \mathrm{~N} /{ }^{14} \mathrm{~N}\right)$ in indole using the gas chromatography-mass spectrometry (GC-MS). The sample of organic compound indole was divided into two parts - one part was designated as a control sample (untreated), and another part was considered as biofield energy treated sample, which was subjected to Mr. Trivedi's biofield energy treatment (The Trivedi Effect ${ }^{\mathbb{R}}$ ). The biofield energy treated indole sample was analyzed at different time intervals and were symbolized as T1, T2, T3, and T4 to understand the effect of the biofield energy on isotopic abundance ratio with respect to the time. From the GC-MS spectra, the presence of the molecular ion peak $\mathrm{C}_{8} \mathrm{H}_{7} \mathrm{~N}^{+}(\mathrm{m} / z$ 117) along with major fragmented peaks $\mathrm{C}_{7} \mathrm{H}_{6}{ }^{+}\left(m / z\right.$ 90), $\mathrm{C}_{7} \mathrm{H}_{5}^{+}\left(m / z\right.$ 89), $\mathrm{C}_{5} \mathrm{H}_{3}{ }^{+}(m / z 63), \mathrm{C}_{4} \mathrm{H}_{2}{ }^{+}(m / z 50), \mathrm{C}_{3} \mathrm{H}_{3}{ }^{+}\left(m / z\right.$ 39), and $\mathrm{C}_{2} \mathrm{H}_{4}(\mathrm{~m} / z$ 28) were observed in both control and biofield treated samples. Only, the relative peak intensities of the fragmented ions in the biofield treated indole was notably changed as compared to the control sample with respect to the time. The isotopic abundance ratio analysis of indole using GC-MS revealed that the isotopic abundance ratio of $\mathrm{P}_{\mathrm{M}+1} / \mathrm{P}_{\mathrm{M}}$ in the biofield energy treated indole at T1 and T2 was significantly decreased by 44.28 and $28.18 \%$ as compared to the control sample. On the contrary, the isotopic abundance ratio of $\mathrm{P}_{\mathrm{M}+1} / \mathrm{P}_{\mathrm{M}}$ in the biofield energy treated sample at $\mathrm{T} 3$ and $\mathrm{T} 4$, was significantly increased by 41.22 and $180.88 \%$, respectively as compared to the control sample. Overall, the isotopic abundance ratio of $\mathrm{P}_{\mathrm{M}+1} / \mathrm{P}_{\mathrm{M}}\left({ }^{2} \mathrm{H} /{ }^{1} \mathrm{H}\right.$ or ${ }^{13} \mathrm{C} /{ }^{12} \mathrm{C}$ or $\left.{ }^{15} \mathrm{~N} /{ }^{14} \mathrm{~N}\right)$ was significantly altered in the biofield energy treated indole as compared to the control with respect to the time. The biofield treated indole with the altered isotopic abundance ratio might have altered the physicochemical properties and rate of reaction. This biofield energy treated indole might be more useful as a chemical intermediate in the production of pharmaceuticals, chemicals, plastics, dyes, and perfumes.
\end{abstract}

Keywords: Biofield Energy Treatment, The Trivedi Effect ${ }^{\circledR}$, Indole, Isotopic Abundance, Gas Chromatography-Mass Spectrometry

\section{Introduction}

The indole is a bicyclic heteroaromatic compound, widely distributed in both the plant and animal kingdom by nature [1]. It is an integral part of the amino acid tryptophan, neurotransmitter serotonin, the plant hormone auxin, the anti- inflammatory drug indomethacin, the beta-blocker pindolol, etc. $[2,3]$. Besides the medicinal applications, indole-based compounds have a significant importance in the commodity markets, such as dyes, plastics, agriculture, over-the-counter drugs, vitamin supplements, flavour enhancers, and perfumery $[4,5]$. These are all commodity markets, distinct from the explosion of medicinal uses that have been 
discovered for indole-containing substances [5]. In spite of the huge application of indole, it has potential acute health effects, i.e. very hazardous to the eye, and skin on contact (i.e. inflammation characterized by redness, watering, and itching). High concentrations of indole are toxic to cells due to perturbations in membrane potential. The substance is toxic to lungs, mucous membranes and repeated or prolonged exposure to the substance can produce target organs damage [6-8]. Research investigation claimed indole showing the leukemogenic effect in mice [9]. Therefore, the toxicity and hazardous effect of indole is a very important scientific limitation to its application. The physical hazards, intrinsic human health hazards and ecotoxicity are directly linked to a chemical's intrinsic physicochemical properties [10].

The alternation of the isotopic composition in the naturally available form of indole to stable, heavier isotopic form might be an alternative approach for the modification of intrinsic physicochemical and structural properties of indole. The analysis of the stable isotopic ratio widely used in the fields of geographical, biochemistry, metabolism, medical research, sports, agricultural, and food authenticity, etc. [1115]. Other than the natural process, the isotopic abundance of a molecule can be altered by means of chemical reactions $[12,16]$. The literature reported that Mr. Trivedi's biofield energy treatment has the remarkable capability to alter the isotopic abundance ratios of chemical compounds [17-20]. An electromagnetic field present in an around the human body which emits the electromagnetic waves in the form of the bio-photons, and it is commonly known as biofield [2123]. The energy can be harnessed from the universe and then, it can be applied to the living and non-living objects to achieve the alterations in the characteristic properties by the healing practitioner. The applications of The Trivedi Effect ${ }^{\circledR}$ have gained scientific attention in the field of chemical science [17-20, 24], materials science [25-27], agricultural science [28-30] genetics [31-34], biotechnology [35-36], nutraceuticals [37] pharmaceuticals [38-40], and medical sciences [41, 42].

The mass spectrometry (MS) technique is the main choice, and the conventional analytical technique gas chromatography-mass spectrometry (GC-MS) can perform isotope ratio measurement at low micro molar concentration levels with sufficient precision [43-46]. Mr. Trivedi's biofield energy treatment (The Trivedi Effect ${ }^{\mathbb{B}}$ ) has an outstanding ability to alter the physicochemical and thermal properties of indole such as improved physicochemical, thermal properties, and force constant that might affect the rate of chemical reaction [24]. Based on all these aspects, the current study was designed to investigate the isotopic abundance ratio of $\mathrm{P}_{\mathrm{M}+1} / \mathrm{P}_{\mathrm{M}}\left({ }^{2} \mathrm{H} /{ }^{1} \mathrm{H}\right.$ or ${ }^{13} \mathrm{C} /{ }^{12} \mathrm{C}$ or $\left.{ }^{15} \mathrm{~N} /{ }^{14} \mathrm{~N}\right)$ in the biofield energy treated indole using the GC-MS.

\section{Materials and Method}

\subsection{Chemicals and Reagents}

The organic compound indole was procured from SD Fine
Chem Pvt. Ltd., India. All the other chemicals used in this experiment were analytical grade purchased from the local vendors.

\subsection{Biofield Energy Treatment Strategy}

The sample of indole was divided into two parts; one was kept as a control (untreated) and the other part was subjected to biofield energy treatment and coded as treated sample. The sample for the biofield energy treatment was handed over to Mr. Trivedi under standard laboratory condition. Mr. Trivedi provided the biofield energy treatment through his unique energy transmission process for 5 minutes without touching the sample. Finally, the biofield energy treated sample was returned in the similar sealed condition for further GC-MS analysis.

\subsection{Gas Chromatograph-Mass Spectrometry (GC-MS)}

The GC-MS analysis was conducted on Perkin Elmer/Auto system XL with Turbo mass, USA. The GC-MS was accomplished in a silica capillary column. It was furnished with a quadrupole detector with pre-filter. This mass spectrometer was functioning in an electron ionization positive/negative, and chemical ionization mode at the electron ionization energy of $70 \mathrm{eV}$. The mass range: 10-650 Daltons (amu), stability: $\pm 0.1 \mathrm{~m} / \mathrm{z}$ mass accuracy over 48 hours. The characterization of analyses was performed by considering the retention time and the mass spectra of identifying substances by comparing with the references.

\subsection{Method of GC-MS Analysis and Calculation of Isotopic Abundance Ratio}

The GC-MS analysis of biofield energy treated indole was analyzed at the different time intervals and symbolized as T1, T2, T3, and T4, respectively. The GC-MS data were obtained in the form of $\%$ abundance $v s$. mass to charge ratio $(\mathrm{m} / \mathrm{z})$, which was known as mass spectrum. The natural abundance of each isotope can be predicted from the comparison of the height of the isotope peak with respect to the base peak, i.e. relative abundance in the mass spectra [43]. The natural isotopic abundances of some elements are obtained from several literatures [43-46] and the values presented in Table 1.

Table 1. The isotopic composition (the natural isotopic abundance) of the elements.

\begin{tabular}{llllll}
\hline Element (A) & Symbol & Mass & $\begin{array}{l}\text { \% Natural } \\
\text { Abundance }\end{array}$ & $\begin{array}{l}\boldsymbol{A}+\mathbf{1} \\
\text { Factor }\end{array}$ & $\begin{array}{l}\boldsymbol{A}+\mathbf{2} \\
\text { Factor }\end{array}$ \\
\hline Hydrogen & ${ }^{1} \mathrm{H}$ & 1 & 99.9885 & & \\
& ${ }^{2} \mathrm{H}$ & 2 & 0.0115 & $0.015 \mathrm{n}_{\mathrm{H}}$ & \\
Carbon & ${ }^{12} \mathrm{C}$ & 12 & 98.892 & & \\
& ${ }^{13} \mathrm{C}$ & 13 & 1.108 & $1.1 \mathrm{n}_{\mathrm{C}}$ & \\
Nitrogen & ${ }^{14} \mathrm{~N}$ & 14 & 99.60 & & \\
& ${ }^{15} \mathrm{~N}$ & 15 & 0.40 & $0.40 \mathrm{n}_{\mathrm{N}}$ \\
\hline
\end{tabular}

$A$ : Element; n: no of $\mathrm{H}, \mathrm{C}$, and N.

The following general method was used for calculating the isotopic abundance ratio:

$\mathrm{P}_{\mathrm{M}}$ stands for the relative peak intensity of the parent 
molecular ion $\left[\mathrm{M}^{+}\right]$expressed in percentage. In other way, it indicates the probability to have $A$ elements (for $e . g .{ }^{12} \mathrm{C},{ }^{1} \mathrm{H}$, ${ }^{14} \mathrm{~N}$, etc.) contributions to the mass of the parent molecular ion $\left[\mathrm{M}^{+}\right]$.

$\mathrm{P}_{\mathrm{M}+1}$ represents the relative peak intensity of the isotopic molecular ion $\left[(\mathrm{M}+1)^{+}\right]$expressed in percentage

$=\left(\right.$ no. of $\left.{ }^{13} \mathrm{C} \times 1.1 \%\right)+\left(\right.$ no. of $\left.{ }^{15} \mathrm{~N} \times 0.40 \%\right)+\left(\right.$ no. of ${ }^{2} \mathrm{H} \times$ $0.015 \%)$

i.e. the probability to have $A+1$ elements (for $e . g .{ }^{13} \mathrm{C},{ }^{2} \mathrm{H}$, ${ }^{15} \mathrm{~N}$, etc.) contributions to the mass of the isotopic molecular ion $\left[(\mathrm{M}+1)^{+}\right]$

Isotopic abundance ratio (IAR) for $A+1$ elements $=\mathrm{P}_{\mathrm{M}+}$ ${ }_{1} / \mathrm{P}_{\mathrm{M}}$

Percentage $(\%)$ change in isotopic abundance ratio = $\left.\left[\left(\mathrm{IAR}_{\text {Treated }}-\mathrm{IAR}_{\text {Control }}\right) / \mathrm{IAR}_{\text {Control }}\right) \times 100\right]$

Where, $\mathrm{IAR}_{\text {Treated }}$ is isotopic abundance ratio in the treated sample and $\mathrm{IAR}_{\text {Control }}$ is isotopic abundance ratio in the control sample.

\section{Results and Discussion}

The mass spectra obtained by the instrumental analysis for the control and biofield energy treated indole $\left(\mathrm{C}_{8} \mathrm{H}_{7} \mathrm{~N}\right)$ in the positive ion mode are shown in Figure 1 and 2, respectively. In Figure 1, it was observed that the presence of the parent molecular ion peak of control sample at $\mathrm{m} / z 117$ (calculated 117.06 for $\left.\mathrm{C}_{8} \mathrm{H}_{7} \mathrm{~N}^{+}\right)$at the retention time $\left(\mathrm{R}_{\mathrm{t}}\right)$ of $12.77 \mathrm{~min}$ along with five major fragmented peaks that were well matched with the literature $[47,48]$. The biofield energy treated indole at $\mathrm{T} 1, \mathrm{~T} 2, \mathrm{~T} 3$, and $\mathrm{T} 4$ exhibited the parent molecular ion peaks $\left(\mathrm{C}_{8} \mathrm{H}_{7} \mathrm{~N}^{+}\right)$at $m / z 117$ at the $\mathrm{R}_{\mathrm{t}}$ of 12.66 , $12.72,12.68$, and $12.77 \mathrm{~min}$, respectively, which were very close to the $\mathrm{R}_{\mathrm{t}}$ of the control sample. The molecular ion $(\mathrm{m} / \mathrm{z}$ 117, base peak) lost $\mathrm{HCN}$ and $\mathrm{H}_{2} \mathrm{CN}$ and shown the strong peak at $m / z 90\left(\mathrm{C}_{7} \mathrm{H}_{6}^{+}\right.$, relative abundance $\left.85 \%\right)$ and 89 $\left(\mathrm{C}_{7} \mathrm{H}_{5}^{+}\right.$, relative abundance $\left.85 \%\right)$ in both the control and treated indole. Further, the indole produced the fragmentations of $\mathrm{C}_{5} \mathrm{H}_{3}{ }^{+}$(m/z 63), $\mathrm{C}_{4} \mathrm{H}_{2}{ }^{+}$(m/z 50), $\mathrm{C}_{3} \mathrm{H}_{3}{ }^{+}(\mathrm{m} / \mathrm{z}$ $39)$, and $\mathrm{C}_{2} \mathrm{H}_{4}(\mathrm{~m} / z 28)$ in both the samples (Figure 1 and 2). The biofield energy treated indole at T1, T2, T3, and T4 showed a similar fragmentation pattern as the control sample (Figure 1 and 2). Only, the relative peak intensities of the biofield treated sample were significantly altered as compared to the control sample (Figure 1 and 2).

The molecule indole $\left(\mathrm{C}_{8} \mathrm{H}_{7} \mathrm{~N}\right)$ is a heterocyclic compound and comprises several atoms of $\mathrm{H}, \mathrm{C}$, and $\mathrm{N}$. The relative abundances for the isotopic contributions to the peaks in various ion clusters reflect the contributions of several different isotopes to the same peak [44, 46, 49, 50]. The most intense peak $\mathrm{P}_{\mathrm{M}}$ in this cluster was at $\mathrm{m} / \mathrm{z} 117$, and its size is determined solely by the most abundant elemental composition which is defined as ' $100 \%$ '. $\mathrm{P}_{\mathrm{M}+1}$ of indole can be calculated theoretically according to the method described previously.

$\mathrm{P}\left({ }^{13} \mathrm{C}\right)=\left[(8 \times 1.1 \%) \times 100 \%\right.$ (the actual size of the $\mathrm{M}^{+}$ peak) $] / 100 \%=8.8 \%$

$$
\mathrm{P}\left({ }^{2} \mathrm{H}\right)=[(7 \times 0.015 \%) \times 100 \%] / 100 \%=0.105 \%
$$

$\mathrm{P}\left({ }^{15} \mathrm{~N}\right)=[(1 \times 0.40 \%) \times 100 \%] / 100 \%=0.4 \%$

Thus, $\mathrm{P}_{\mathrm{M}+1}$ i.e. ${ }^{13} \mathrm{C},{ }^{2} \mathrm{H}$, and ${ }^{15} \mathrm{~N}$ contributions from $\mathrm{C}_{8} \mathrm{H}_{7} \mathrm{~N}^{+}$ to $m / z 118$ is $9.305 \%$.

Theoretically, it has been found that the coincidental of both carbons being ${ }^{13} \mathrm{C}$ is approximately 1 in 10,000 and the deuterium did not contribute much any of the $\mathrm{m} / \mathrm{z}$ ratios naturally as the natural abundance of deuterium is too small [51-54]. From the above calculations, ${ }^{13} \mathrm{C}$ and ${ }^{15} \mathrm{~N}$ have the major contributions from indole to the isotopic peak $\mathrm{m} / z 118$.

$\mathrm{P}_{\mathrm{M}}$ and $\mathrm{P}_{\mathrm{M}+1}$ for the control and biofield energy treated indole at $\mathrm{m} / \mathrm{z} 117$ and 118 , respectively, were achieved from the observed relative intensity of $\left[\mathrm{M}^{+}\right]$and $\left[(\mathrm{M}+1)^{+}\right]$peaks in the mass spectra, respectively and are shown in Table 2 . The percentage change in the isotopic abundance ratio of $\mathrm{P}_{\mathrm{M}+1} / \mathrm{P}_{\mathrm{M}}$ in the biofield treated indole at T1, T2, T3, and T4 are presented in Table 2. The isotopic abundance ratio analysis of indole using mass spectrometry revealed that the isotopic abundance ratio of $\mathrm{P}_{\mathrm{M}+1} / \mathrm{P}_{\mathrm{M}}$ in biofield energy treated indole at $\mathrm{T} 1$ and $\mathrm{T} 2$ was decreased by 44.28 and $28.18 \%$, respectively as compared to the control sample (Table 2 and Figure 3). On the contrary, the isotopic abundance ratio $\mathrm{P}_{\mathrm{M}+1} / \mathrm{P}_{\mathrm{M}}$ in the biofield energy treated sample at T3 and T4 was significantly increased by 41.22 and $180.88 \%$, respectively in comparison to the control sample (Table 2 and Figure 3). From the Figure 3, it was clear that there was a different effect of biofield energy on the isotopic abundance ratio $\left(\mathrm{P}_{\mathrm{M}+1} / \mathrm{P}_{\mathrm{M}}\right)$ in the biofield energy treated indole with respect to the time. After biofield energy treatment, the isotopic abundance ratio at $\mathrm{T} 1$ and $\mathrm{T} 2$ was surprisingly fall followed by the improvement in isotopic abundance ratio at $\mathrm{T} 3$ and T4 than control. The observation proposing that there might be an incident of inter-conversion of mass between atoms leads to variations of abundance with respect to time after biofield energy treatment. The results indicated that the biofield treated sample had the time dependent response for the alternation of isotopic composition.

Table 2. The GC-MS isotopic abundance analysis results of control and biofield energy treated indole.

\begin{tabular}{|c|c|c|c|c|c|}
\hline \multirow{2}{*}{ Parameter } & \multirow{2}{*}{ Control Indole } & \multicolumn{4}{|c|}{ Treated Indole } \\
\hline & & T1 & T2 & T3 & T4 \\
\hline $\mathrm{P}_{\mathrm{M}}$ at $m / z 117(\%)$ & 100 & 100 & 100 & 100 & 100 \\
\hline $\mathrm{P}_{\mathrm{M}+1}$ at $m / z 118(\%)$ & 21.86 & 12.18 & 15.70 & 30.87 & 61.40 \\
\hline $\mathrm{P}_{\mathrm{M}+1} / \mathrm{P}_{\mathrm{M}}$ & 0.2186 & 0.1218 & 0.1570 & 0.3087 & 0.6140 \\
\hline$\%$ Change of isotopic abundance ratio $\left(\mathrm{P}_{\mathrm{M}+1} / \mathrm{P}_{\mathrm{M}}\right)$ & & -44.28 & -28.18 & 41.22 & 180.88 \\
\hline
\end{tabular}

T1, T2, T3, and T4: different time intervals for the analysis of biofield energy treated sample; $\mathrm{P}_{\mathrm{M}}$ : the relative peak intensity of the parent molecular ion $\left[\mathrm{M}^{+}\right]$; $\mathrm{P}_{\mathrm{M}+1}$ : the relative peak intensity of the isotopic molecular ion $\left[(\mathrm{M}+1)^{+}\right]$. 


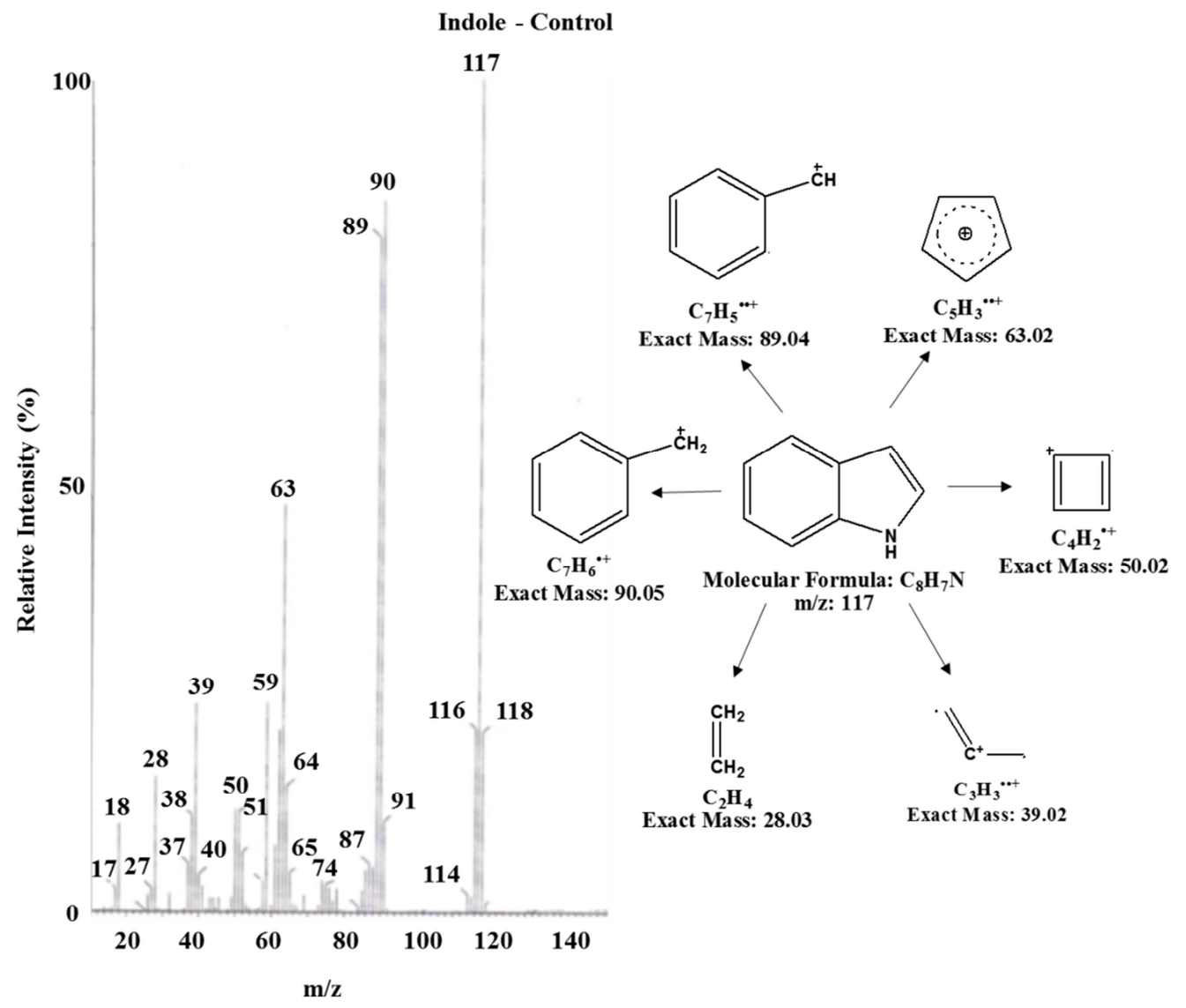

Figure 1. The GC-MS spectrum and possible fragmentations of the control sample of indole.
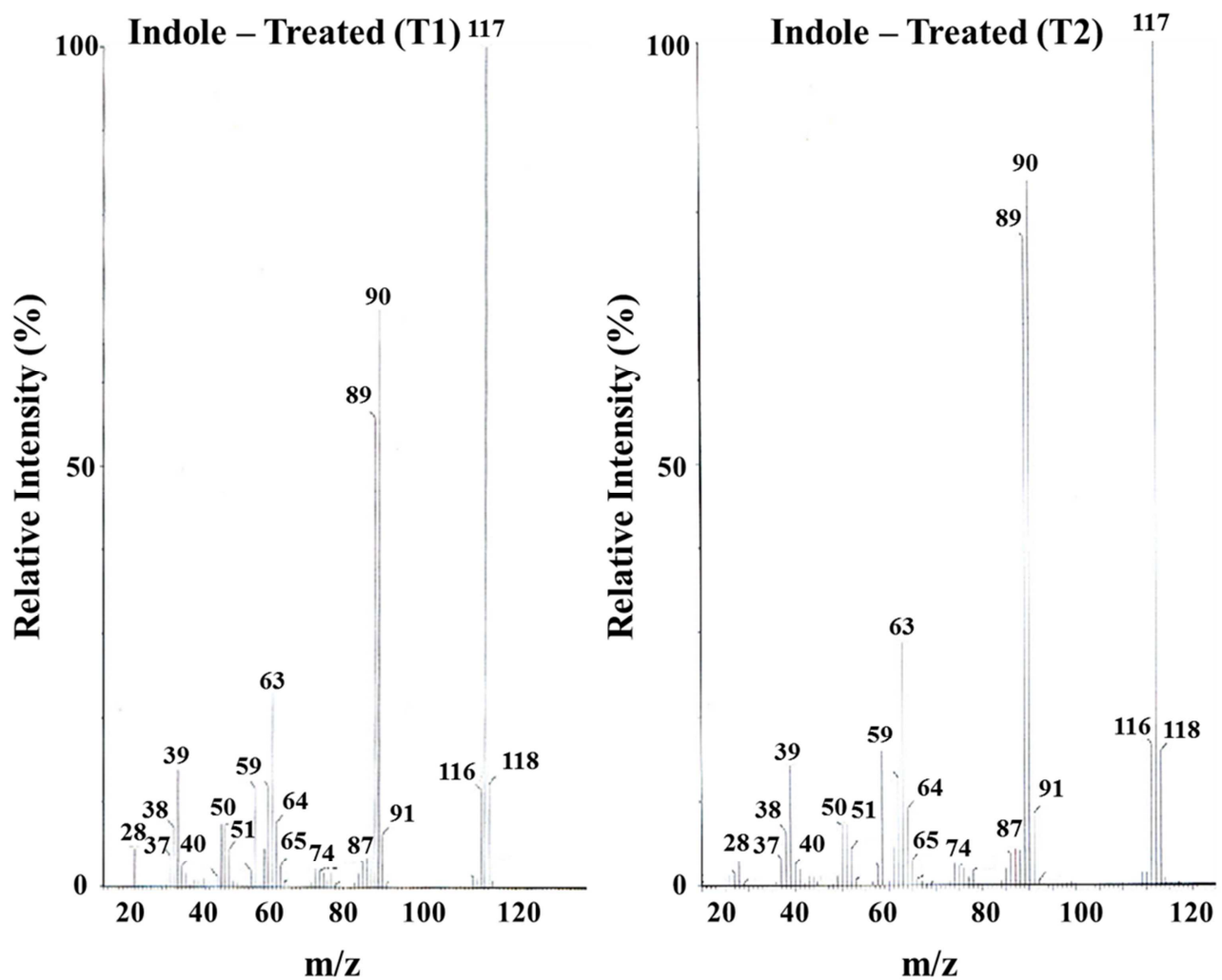

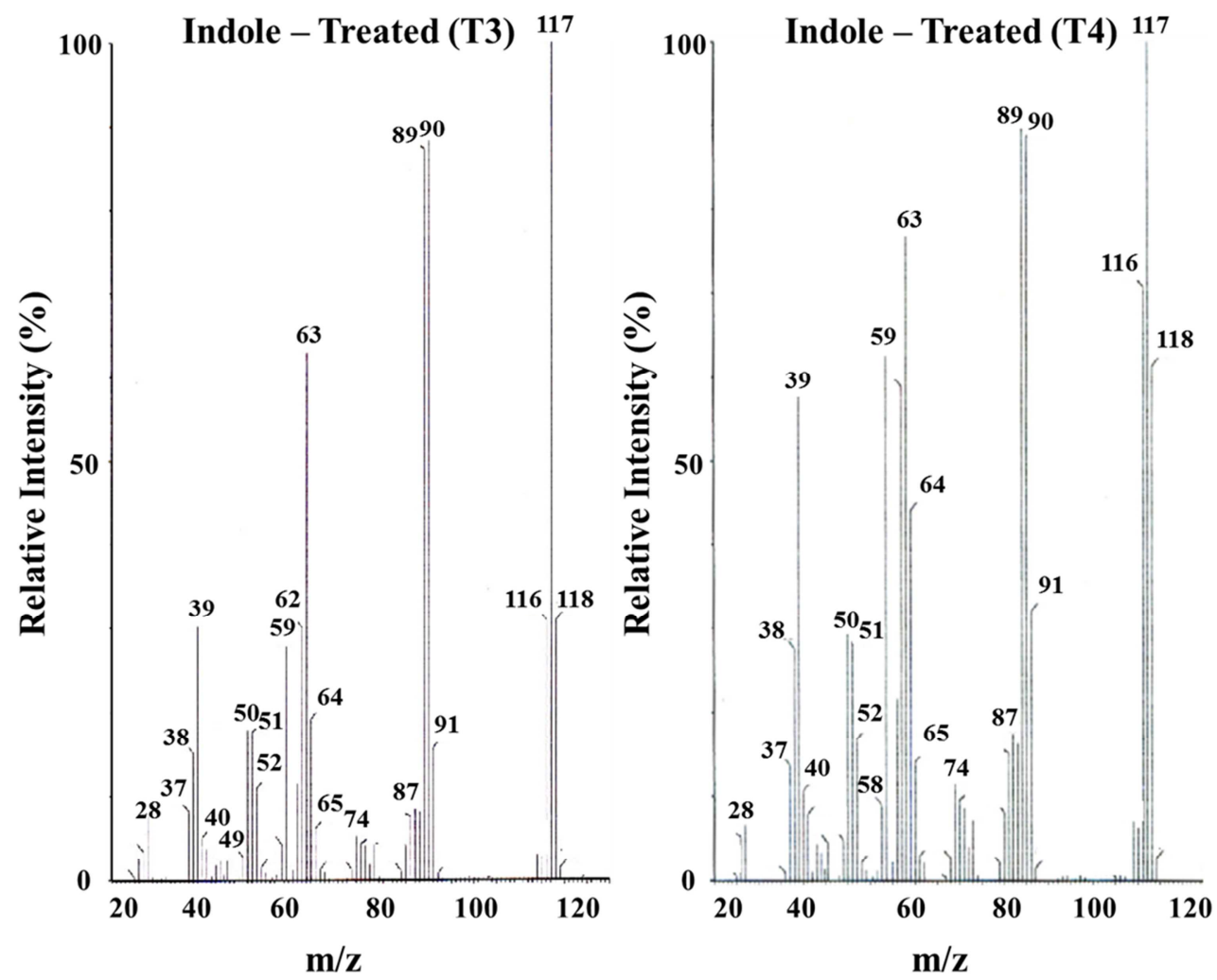

Figure 2. The GC-MS spectrum of biofield energy treated indole analyzed at the different time intervals $T 1, T 2, T 3$, and $T 4$.

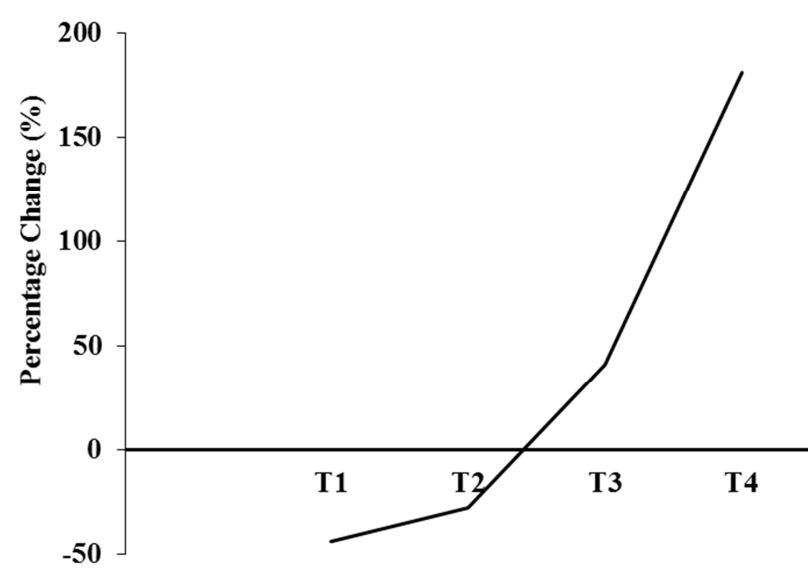

Figure 3. Percent change in the isotopic abundance ratio of $P_{M+1} / P_{M}$ in the biofield treated indole as compared to the control.

Exchange of the isotopic composition of the molecule alters the vibrational energy $[55,56]$. The vibrational energy depends on the reduced mass $(\mu)$ for a diatomic molecule as shown in the below:

$$
E_{0}=\frac{h}{4 \pi} \sqrt{\frac{f}{\mu}}
$$

Where, $\mathrm{E}_{0}=$ the vibrational energy of a harmonic oscillator at absolute zero or zero point energy; $\mathrm{f}=$ force constant and $\mu$ (reduced mass) $=\frac{m_{a} m_{b}}{m_{a}+m_{b}}$

The reduced mass $(\mu)$ of some probable isotopic bonds was calculated and presented in Table 3. The result showed that $\mu$ of normal ${ }^{12} \mathrm{C}-{ }^{12} \mathrm{C}(\mu=6),{ }^{1} \mathrm{H}-{ }^{12} \mathrm{C}(\mu=0.92),{ }^{14} \mathrm{~N}-{ }^{1} \mathrm{H}$ $(\mu=0.93)$, and ${ }^{14} \mathrm{~N}-{ }^{12} \mathrm{C}(\mu=6.46)$ bonds were increased in the case of heavier isotopes i.e. ${ }^{13} \mathrm{C}-{ }^{12} \mathrm{C} \quad(\mu=6.24),{ }^{2} \mathrm{H}-{ }^{12} \mathrm{C}$ $(\mu=1.71), \quad{ }^{15} \mathrm{~N}-{ }^{1} \mathrm{H} \quad(\mu=0.94), \quad{ }^{14} \mathrm{~N}-{ }^{2} \mathrm{H} \quad(\mu=1.75), \quad{ }^{15} \mathrm{~N}-{ }^{12} \mathrm{C}$ $(\mu=6.67)$, and ${ }^{15} \mathrm{~N}-{ }^{13} \mathrm{C} \quad(\mu=6.96)$. The heavier isotopic molecules have lower diffusion velocity, mobility, evaporation rate, thermal decomposition and reaction rate, but having a higher binding energy than lighter molecules [55-58]. Therefore, the indole after biofield energy treatment, the bond strength, stability, and binding energy might be increase due to the higher reduced mass $(\mu)$.

Table 3. Possible isotopic bonds and their effect on the vibrational energy in indole.

\begin{tabular}{llll}
\hline $\begin{array}{l}\text { Isotopes } \\
\text { bond }\end{array}$ & $\begin{array}{l}\text { Isotope } \\
\text { type }\end{array}$ & $\begin{array}{l}\text { Reduced mass }(\boldsymbol{\mu}) \\
\left(\mathbf{m}_{\mathrm{A}} \cdot \mathbf{m}_{\mathrm{B}} /\left(\mathbf{m}_{\mathrm{A}}+\mathbf{m}_{\mathrm{B}}\right)\right.\end{array}$ & $\begin{array}{l}\text { Zero point vibrational } \\
\text { energy }\left(\boldsymbol{E}_{\boldsymbol{\theta}}\right)\end{array}$ \\
\hline${ }^{12} \mathrm{C}-{ }^{12} \mathrm{C}$ & Lighter & 6.00 & Higher \\
${ }^{13} \mathrm{C}-{ }^{12} \mathrm{C}$ & Heavier & 6.24 & Smaller \\
${ }^{1} \mathrm{H}-{ }^{12} \mathrm{C}$ & Lighter & 0.92 & Higher \\
${ }^{2} \mathrm{H}-{ }^{12} \mathrm{C}$ & Heavier & 1.71 & Smaller \\
${ }^{14} \mathrm{~N}-{ }^{-1} \mathrm{H}$ & Lighter & 0.93 & Higher \\
${ }^{15} \mathrm{~N}-{ }^{-1} \mathrm{H}$ & Heavier & 0.94 & Smaller \\
${ }^{14} \mathrm{~N}-{ }^{-} \mathrm{H}$ & Heavier & 1.75 & Smaller \\
${ }^{14} \mathrm{~N}-{ }^{12} \mathrm{C}$ & Lighter & 6.46 & Higher \\
${ }^{15} \mathrm{~N}-{ }^{12} \mathrm{C}$ & Heavier & 6.67 & Smaller \\
${ }^{15} \mathrm{~N}-{ }^{13} \mathrm{C}$ & Heavier & 6.96 & Smaller \\
\hline
\end{tabular}

$\mathrm{m}_{\mathrm{A}}$ : mass of atom $\mathrm{A} ; \mathrm{m}_{\mathrm{B}}$ : mass of atom $\mathrm{B}$, here $\mathrm{A}$ and $\mathrm{B}$ may be $\mathrm{C}$ or $\mathrm{H}$ or $\mathrm{N}$.

The isotopic abundance ratio of $\mathrm{P}_{\mathrm{M}+1} / \mathrm{P}_{\mathrm{M}}\left({ }^{2} \mathrm{H} /{ }^{1} \mathrm{H}\right.$ or ${ }^{13} \mathrm{C} /{ }^{12} \mathrm{C}$ or $\left.{ }^{15} \mathrm{~N} /{ }^{14} \mathrm{~N}\right)$ in the biofield treated indole was significantly increased at $\mathrm{T} 3$ and $\mathrm{T} 4$ as compared to the control sample. The modern physics explained that the 
neutrinos change identities which are only possible if the neutrinos possess mass and have the ability to interchange their phase internally from one phase to another. Therefore, the neutrinos have the ability to interact with protons and neutrons in the nucleus. There was a close relation between neutrino and the isotope formation [59, 60]. The biofield energy significantly altered in the isotopic composition at the molecular level might be due to change in neutron to proton ratio in the nucleus. It is hypothesized that the changes in isotopic abundance could be due to changes in nuclei possibly through the interference of neutrino particles via biofield energy treatment. The biofield treated indole with altered stable isotopic abundance ratio, might have changed the physicochemical and thermal properties, force constant and controlled reaction rate. The current findings were well collaborated with the previous results [24]. The biofield treated indole might be more useful in pharmaceutical, chemical, plastic, dye, and perfume industries as an intermediate for the production of their fine finished product.

\section{Conclusions}

The isotopic abundance ratio analysis of indole using gas chromatography-mass spectrometry (GC-MS) of both the control and biofield energy treated sample concluded that there was a significant influence of biofield energy treatment on isotopic abundance ratio. The presence of the molecular ion peak $\mathrm{C}_{8} \mathrm{H}_{7} \mathrm{~N}^{+}(m / z$ 117) along with major fragmented peaks $\mathrm{C}_{7} \mathrm{H}_{6}{ }^{+}(m / z 90), \mathrm{C}_{7} \mathrm{H}_{5}{ }^{\cdot+}(m / z 89), \mathrm{C}_{5} \mathrm{H}_{3}{ }^{\cdot++}(m / z \quad 63)$, $\mathrm{C}_{4} \mathrm{H}_{2}{ }^{{ }^{*+}}$ (m/z 50), $\mathrm{C}_{3} \mathrm{H}_{3}{ }^{\cdot++}$ ( $m / z$ 39), and $\mathrm{C}_{2} \mathrm{H}_{4}(\mathrm{~m} / z$ 28) were observed in both control and biofield treated samples. The relative peak intensities of the fragmented ions in the biofield treated sample were altered as compared to the control sample. The isotopic abundance ratio analysis of indole revealed that the isotopic abundance ratio of $\mathrm{P}_{\mathrm{M}+1} / \mathrm{P}_{\mathrm{M}}$ in the biofield energy treated sample at $\mathrm{T} 1$ and $\mathrm{T} 2$ was significantly decreased by 44.28 and $28.18 \%$ as compared to the control sample. On the other hand, the isotopic abundance ratio of biofield energy treated indole exhibited that the isotopic abundance ratio of $\mathrm{P}_{\mathrm{M}+1} / \mathrm{P}_{\mathrm{M}}$ at $\mathrm{T} 3$ and $\mathrm{T} 4$ was significantly increased by 41.22 and $180.88 \%$, respectively as compared to the control sample. It was observed that the isotopic abundance ratio of $\mathrm{P}_{\mathrm{M}+1} / \mathrm{P}_{\mathrm{M}}\left({ }^{2} \mathrm{H} /{ }^{1} \mathrm{H}\right.$ or ${ }^{13} \mathrm{C} /{ }^{12} \mathrm{C}$ or $\left.{ }^{15} \mathrm{~N} /{ }^{14} \mathrm{~N}\right)$ in the biofield treated sample was altered with respect to the time. The biofield treated indole with altered isotopic abundance ratio, might have altered physicochemical and thermal properties, force constant and controlled reaction rate. The biofield energy treated indole could be more helpful in the pharmaceutical, chemical, plastic, dye, and perfume industries as a raw material for the production of fine finished products.

\section{Abbreviations}

A: Element; GC-MS: Gas chromatography-mass spectrometry; $m / z$ : Mass-to-charge ratio; M: Mass of the parent molecule; $\mathrm{P}_{\mathrm{M}}$ : the relative peak intensity of the parent molecular ion $\left[\mathrm{M}^{+}\right] ; \mathrm{P}_{\mathrm{M}+1}$ : the relative peak intensity of the isotopic molecular ion $\left[(\mathrm{M}+1)^{+}\right]$.

\section{Acknowledgements}

The authors would like to acknowledge the Sophisticated Instrumentation Centre for Applied Research and Testing (SICART) Gujarat, India for providing the instrumental facility. The authors are very grateful for the support from Trivedi Science, Trivedi Master Wellness and Trivedi Testimonials in this research work.

\section{References}

[1] Radwanski ER, Last RL (1995) Tryptophan biosynthesis and metabolism: Biochemical and molecular genetics. Plant Cell 7: 921-934.

[2] Berger M, Gray JA, Roth BL (2009) The expanded biology of serotonin. Annu Rev Med 60: 355-366.

[3] Van Order RB, Lindwall HG (1942) Indole. Chem Rev 30: 6996.

[4] Kaushik NK, Kaushik N, Attri P, Kumar N, Kim CH, Verma AK, Choi EH (2013) Biomedical importance of indoles. Molecules 18: 6620-6662.

[5] Barden TC (2011) Indoles: Industrial, agricultural and overthe-counter uses. Top Heterocycl Chem 26: 31-46.

[6] http://www.sciencelab.com/msds.php?msdsId=9924362.

[7] Kim J, Hong H, Heo A, Park W (2013) Indole toxicity involves the inhibition of adenosine triphosphate production and protein folding in Pseudomonas putida. FEMS Microbiol Lett 343: 89-99.

[8] http://www.pesticideinfo.org/Detail_Chemical.jsp?Rec_Id=PC 33025.

[9] Dzhioev FK (1974) Study of the carcinogenic action of tryptophan and certain of its metabolites. Vopr Onkol 20: 7581 .

[10] A Framework to Guide Selection of Chemical Alternatives (2014) The National Academies Press. Chapter 5: Physicochemical Properties and Environmental Fate.

[11] Winderl C, Penning H, von Netzer F, Meckenstock RU, Lueders T (2010) DNA-SIP identifies sulfate-reducing Clostridia as important toluene degraders in tar-oilcontaminated aquifer sediment. The ISME Journal 4: 13141325 .

[12] Muccio Z, Jackson GP (2009) Isotope ratio mass spectrometry. Analyst 134: 213-222.

[13] Ben-David M, Flaherty EA (2012) Stable isotopes in mammalian research: A beginner's guide. J Mammal 93: 312328.

[14] Scott, KM, Fox, G, Girguis PR (2011) Measuring isotope fractionation by autotrophic microorganisms and enzymes. Methods Enzymol 494: 281-299. 
[15] Morgan JLL, Skulan JL, Gordon GW, Romaniello SJ, Smith SM, Anbar AD (2012) Rapidly assessing changes in bone mineral balance using natural stable calcium isotopes. Proc Natl Acad Sci USA 109: 9989-9994.

[16] Hayes JM (2004) An introduction to isotopic calculations Woods Hole Oceanographic Institution, Woods Hole, MA 02543, USA.

[17] Trivedi MK, Branton A, Trivedi D, Nayak G, Saikia G, Jana S (2015) Evaluation of isotopic abundance ratio of naphthalene derivatives after biofield energy treatment using gas chromatography-mass spectrometry. American Journal of Applied Chemistry 3: 194-200.

[18] Trivedi MK, Branton A, Trivedi D, Nayak G, Saikia G, Jana S (2015) Isotopic abundance analysis of biofield treated benzene, toluene and $p$-xylene using gas chromatography-mass spectrometry (GC-MS). Mass Spectrom Open Access 1: 102.

[19] Trivedi MK, Branton A, Trivedi D, Nayak G, Saikia G, Jana S (2015) Quantitative determination of isotopic abundance ratio of ${ }^{13} \mathrm{C},{ }^{2} \mathrm{H}$, and ${ }^{18} \mathrm{O}$ in biofield energy treated ortho and meta toluic acid isomers. American Journal of Applied Chemistry 3: 217-223.

[20] Trivedi MK, Branton A, Trivedi D, Nayak G, Saikia G, Jana S (2015) Determination of isotopic abundance of ${ }^{2} \mathrm{H},{ }^{13} \mathrm{C},{ }^{18} \mathrm{O}$, and ${ }^{37} \mathrm{Cl}$ in biofield energy treated dichlorophenol isomers. Science Journal of Analytical Chemistry 4: 1-6.

[21] Hammerschlag $R$, Jain S, Baldwin AL, Gronowicz G, Lutgendor SK, Oschman JL, Yount GL (2012) Biofield research: A roundtable discussion of scientific and methodological issues. J Altern Complement Med 18: 10811086.

[22] Warber SL, Cornelio D, Straughn J, Kile G (2004) Biofield energy healing from the inside. J Altern Complement Med 10: 1107-1113.

[23] Rubik B (2002) The biofield hypothesis: Its biophysical basis and role in medicine. J Altern Complement Med 8: 703-717.

[24] Trivedi MK, Tallapragada RM, Branton A, Trivedi D, Nayak G, Mishra RK, Jana S (2015) Biofield Treatment: A potential strategy for modification of physical and thermal properties of indole. J Environ Anal Chem 2: 152.

[25] Trivedi MK, Tallapragada RM, Branton A, Trivedi D, Nayak G, Latiyal O, Jana S (2015) Evaluation of atomic, physical, and thermal properties of bismuth oxide powder: An impact of biofield energy treatment. American Journal of Nano Research and Applications 3: 94-98.

[26] Trivedi MK, Tallapragada RM, Branton A, Trivedi D, Nayak G, Latiyal O, Jana S (2015) The potential impact of biofield energy treatment on the atomic and physical properties of antimony tin oxide nanopowder. American Journal of Optics and Photonics 3: 123-128.

[27] Trivedi MK, Tallapragada RM, Branton A, Trivedi D, Nayak G, Latiyal O, Jana S (2015) Evaluation of physical and structural properties of biofield energy treated barium calcium tungsten oxide. Advances in Materials 4: 95-100.

[28] Trivedi MK, Branton A, Trivedi D, Nayak G, Mondal SC, Jana S (2015) Evaluation of plant growth, yield and yield attributes of biofield energy treated mustard (Brassica juncea) and chick pea (Cicer arietinum) seeds. Agriculture, Forestry and Fisheries 4: 291-295.
[29] Trivedi MK, Branton A, Trivedi D, Nayak G, Mondal SC, Jana S (2015) Morphological characterization, quality, yield and DNA fingerprinting of biofield energy treated Alphonso mango (Mangifera indica L.). Journal of Food and Nutrition Sciences 3: 245-250.

[30] Trivedi MK, Branton A, Trivedi D, Nayak G, Gangwar M, Jana S (2015) Agronomic characteristics, growth analysis, and yield response of biofield treated mustard, cowpea, horse gram, and groundnuts. International Journal of Genetics and Genomics 3: 74-80.

[31] Trivedi MK, Branton A, Trivedi D, Nayak G, Gangwar M, Jana S (2015) Characterization of phenotype and genotype of biofield treated Enterobacter aerogenes. Transl Med 5: 155.

[32] Trivedi MK, Branton A, Trivedi D, Nayak G, Mondal SC, Jana S (2015) Evaluation of antibiogram, genotype and phylogenetic analysis of biofield treated Nocardia otitidis. Biol Syst Open Access 4: 143.

[33] Trivedi MK, Branton A, Trivedi D, Nayak G, Mondal SC, Jana S (2015) Phenotyping and 16S rDNA analysis after biofield treatment on Citrobacter braakii: A urinary pathogen. J Clin Med Genom 3: 129.

[34] Trivedi MK, Patil S, Shettigar H, Bairwa K, Jana S (2015) Evaluation of phenotyping and genotyping characterization of Serratia marcescens after biofield treatment. J Mol Genet Med 9: 179.

[35] Trivedi MK, Branton A, Trivedi D, Nayak G, Gangwar M, Jana S (2015) Bacterial identification Using 16S rDNA gene sequencing and antibiogram analysis on biofield treated Pseudomonas fluorescens. Clin Med Biochemistry: Open Access 1: 101.

[36] Trivedi MK, Patil S, Mishra RK, Jana S (2015) Thermal and physical properties of biofield treated bile salt and proteose peptone. J Anal Bioanal Tech 6: 256.

[37] Trivedi MK, Rama MT, Branton A, Trivedi D, Nayak G, Gangwar M, Jana S (2015) Biofield treatment: A potential strategy for modification of physical and thermal properties of gluten hydrolysate and ipomoea macroelements. J Nutr Food Sci 5: 414.

[38] Trivedi MK, Branton A, Trivedi D, Nayak G, Singh R, Jana S (2015) Characterisation of physical, spectral and thermal properties of biofield treated resorcinol. Organic Chem Curr Res 4: 146.

[39] Trivedi MK, Branton A, Trivedi D, Nayak G, Singh R, Jana S (2015) Physicochemical and spectroscopic characterization of biofield treated butylated hydroxytoluene. J Food Ind Microbiol 1: 101.

[40] Trivedi MK, Branton A, Trivedi D, Nayak G, Saikia G, Jana S (2015) Physical and structural characterization of biofield treated imidazole derivatives. Nat Prod Chem Res 3: 187.

[41] Trivedi MK, Patil S, Shettigar H, Mondal SC, Jana S (2015) The potential impact of biofield treatment on human brain tumor cells: A time-lapse video microscopy. J Integr Oncol 4: 141.

[42] Trivedi MK, Patil S, Shettigar H, Gangwar M, Jana S (2015) In vitro evaluation of biofield treatment on cancer biomarkers involved in endometrial and prostate cancer cell lines. J Cancer Sci Ther 7: 253-257. 
[43] Rosman KJR, Taylor PDP (1998) Isotopic compositions of the elements 1997 (Technical Report). Pure Appl Chem 70: 217235.

[44] Smith RM (2004) Understanding Mass Spectra: A Basic Approach, Second Edition, John Wiley \& Sons, Inc, ISBN 0471-42949-X.

[45] Weisel CP, Park S, Pyo H, Mohan K, Witz G (2003) Use of stable isotopically labeled benzene to evaluate environmental exposures. J Expo Anal Environ Epidemiol 13: 393-402.

[46] Jürgen H (2004) Gross Mass Spectrometry: A Textbook (2 $2^{\text {nd }}$ Edn) Springer: Berlin.

[47] http://webbook.nist.gov/cgi/cbook.cgi?ID=C120729\&Mask=2 00 .

[48] Powers JC (1968) Mass spectrometry of simple indoles. J Org Chem 33: 2044-2050.

[49] Gordon J (1998) Inside informatics, cambridgesoft.com Article ID: Isotopic Abundance.

[50] Johnstone RAW, Rose ME (1996) Mass Spectrometry for Chemists and Biochemists ( $2^{\text {nd }}$ Edn) Cambridge university press.
[51] Wieser ME (2006) Atomic weights of the elements 2005. Pure Appl Chem 78: 2051-2066.

[52] http://www.chem.uoa.gr/applets/AppletMS/Appl_Ms2.html.

[53] http://www.chemguide.co.uk/analysis/masspec/mplus1.html.

[54] http://www.chemguide.co.uk/analysis/masspec/mplus2.html.

[55] Vanhaecke F, Kyser K (2012) Isotopic composition of the elements In Isotopic Analysis: Fundamentals and applications using ICP-MS (1stedn), Edited by Vanhaecke F, Degryse P. Wiley-VCH GmbH \& Co. KGaA, Weinheim.

[56] Asperger S (2003) Chemical Kinetics and Inorganic Reaction Mechanisms Springer science + Business media, New York.

[57] Lomas JS, Thorne MP (1982) Structure and isotope effects upon the thermal decomposition of carbamates of highly congested tertiary alcohols. J Chem Soc, Perkin Trans 2221 226.

[58] http://www.eolss.net/sample-chapters/c06/e6-104-01-00.pdf.

[59] www.nobelprize.org/nobel prizes/physics/laureates/2015/adva nced-physicsprize2015. pdf.

[60] Balantekin AB (2013) Neutrinos and rare isotopes Journal of Physics: Conference Series 445012022. 